\title{
Testing of Fama and French Factors in Indian Capital Market
}

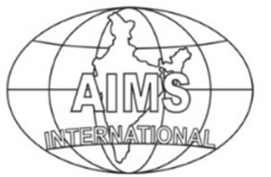

DOI: $10.26573 / 2018.12 .1 .2$

Volume 12, Number 1

January 2018, pp. 11- 23

\author{
T. Manjunatha \\ Visvesvaraya Technological University \\ (tmmanju87@gmail.com)
}

T. Mallikarjunappa

Mangalore University

(tmmallik@yahoo.com)

We test whether Fama and French factors explain the portfolio returns as envisaged in Fama and French (1995). We use National Stock Exchange of India Limited (NSE)'s continuously traded stocks, Nifty Index and other relevant data from July 1996 to June 2010. We form portfolios based on $B E / M E$ and classify them into high medium and low value portfolios. The returns of these portfolios are regressed over independent variables market, size and value. The results show that portfolio returns are explained by all these factors. Our results also show that market has the highest explanatory power followed by size and value. Further, market, size and value factors explain portfolio returns in high and medium BE/ME portfolios and, only market factor explain returns of low BE/ME portfolios.

Keywords: Portfolio Returns, Fama and French Factors, Factor Portfolios, Size, Value, Market

\section{Introduction}

The security/portfolio returns are dependent on many factors. The Fama and French models $\left(1992 ; 1993 ; 1995\right.$ and 1996) suggest that portfolio excess returns $\left(R_{p}-R_{f}\right)$ are influenced by three factors: market excess returns $\left(\mathrm{R}_{\mathrm{m}}-\mathrm{R}_{\mathrm{f}}\right)$, size factor $(\mathrm{SMB})$ and value (HML) factor. Fama and French (1992) tested CAPM using stock returns data between 1941and 1990 from NYSE, AMEX and NASDAQ. They found the combination of size and book-to-market equity captures the cross-sectional variation in average stock returns associated with market beta. Fama and French (1993) identified a model with three common risk factors in the stock returns - an overall market factor, factors related to firm size (SMB) and those related to book-to-market equity (HML). They used a time-series regression approach of Black, Jensen, and Scholes (1972) whose results suggest that size and book-to-market factors were proxies for explaining the differences in average returns across stocks. Kothari and Shanken (1995) questioned the validity of the results of Fama and French (1992) and argued in defence of beta. Kothari et al., (1995) argued that the relation between book-to-market equity and returns was weaker and less consistent than that in Fama and French (1992). Fama and French (1995) studied whether the behaviour of stock prices, in relation to size and book- to- market equity (BE/ME), reflected the behaviour of earnings. They opined that the market and size factors in earnings help explain the market and size factors in returns. But they found no evidence for returns responding to the book-to-market factor in earnings. Fama 
and French (1996a) questioned the validity of the results of Kothari et al. (1995) and argued against beta. They also showed that annual and monthly betas produced the same inferences about the beta premium. They argued that beta premium was more and could not save the CAPM; given the evidence that beta alone cannot explain expected return. Fama and French (1996b) showed that average returns on common stocks were related to firm characteristics like size, earnings/price, cash flow/price, book to market equity, past sales growth, long term past return, and short term past return.

Barber and Lyon (1997) documented that the results of Fama and French (1992) model were similar for financial and non-financial firms. Lough ran (1997) found that Fama and French (1992) empirical findings were driven by two features of the data: a January seasonal in the book-to-market effect, and exceptionally low returns on small, young, growth stocks. Fama and French (1998) studied returns on market, value, and growth portfolios for U.S and twelve major countries from 1975 to 1995 and found that value stocks have higher returns than growth stocks in markets around the world. Davis et al., (2000) found that there was a positive relationship between average returns and book-to-market equity and was as strong for 1929 to 1963 period, as for the subsequent period studied in previous papers. Beltratti and Tria (2002) studied multi-factor models with Italian stock market data for the period 1990-2000 and found the CAPM to be a relevant benchmark for its simplicity and the extended Fama and French (1992) model to be the best candidate for substituting the CAPM.

Faff (2004) testing the Fama and French three-factor model, using daily data drawn from the Australian stock market, found the evidence quite favorable to the model based on formal asset pricing tests. However, when the estimated risk premiums were taken into account, the support for the Fama-French model was less persuasive. In particular, a negative size premium was uncovered questioning its continued existence over the years. Gaunt (2004) studied the Fama and French three factor model in the Australian market and found that the betas were less than one which was contrary to Fama and French who found them to be close to one. Nartea and Djajadikerta (2005) found a significant size effect and a weak BE/ME effect in the case of New Zealand. The French case examined by Ajili (2005) found evidence for the three factor model being of higher explanatory power than the CAPM. Bun doo (2007) studied the emerging African stock markets for evidence of size and value premium, and found that the three factor model holds for the stock exchange of Mauritius but cautioned that the results may be sample specific. Kapur (2007) found that neither of the factors SMB and HML showed a consistent superior ability to explain excess returns for all industries. Homsud et al., (2009) studied Thailand stock market and found that when size and book factors were added into the CAPM, the model could explain portfolio returns better. Hou et.al (2011) found that the choice of price ratio used to construct HML is important in asset pricing tests on international returns. Specifically, HML factors formed on cash flow to price $(\mathrm{C} / \mathrm{P})$ produce fewer model rejections than factors constructed from sorts on B/M. Fama \&French (2012) found that value models must work well in the extremes of the value- growth spectrum. Cakici et.al (2013) examine value and momentum effects in 18 emerging stock markets and find strong evidence for the value effect in all emerging markets and the momentum effect for all but Eastern European market. Fama \& French (2015) found that five-factor model directed at capturing the size, 
value, profitability and investment patterns in average stock returns performs better than the three-factor model of Fama and French (1993). However, Fama \& French (2015) model does not capture the returns on small stocks.

Studying the Indian market, Connor and Sehgal (2003) found that in the threefactor model, the market factor ranks highest in explanatory power, while no clear ranking can be given to the size (SMB) and value (HML) factor. They showed that the three-factor asset-pricing model provided a better description of cross-sectional security returns than the single factor CAPM in the Indian capital markets. Bahl (2007) found that the three small size portfolios have higher average returns than the three large size portfolios confirming the inverse relation between the size and average return of the portfolios. With respect to value effect the study found that for both the size groups, the average returns increase from low to medium book-tomarket ratio and then decrease from medium to high book-to-market ratio. This is contrary to the results of Fama and French (1992) who found a strong positive relation between average return and book to market equity for US stocks as well as Connor and Sehgal (2003) for Indian stocks who found this relation to be positive for small stocks and negative for big stocks. Bahl (2007) suggested for testing the model on portfolios based on different criteria. Taneja (2010) found average returns for both the size groups (Small and Big) decrease from low to medium and from medium to high value effects while the dispersion from mean increases for the same portfolios of size and value. The study rejected the inverse relationship hypothesis between size and average monthly returns of the portfolio as stated by Fama French (1992; 1993; 1996b and 2000), Connor and Sehgal (2003), Ajili (2005), Bun doo (2007) and Bahl (2007). With regard to value factor, an inverse relationship with average monthly returns was found. The study revealed almost perfect positive correlation for size and value factors. It implied that either of the two factors could explain the portfolio returns. Mehta and Chander (2010) studied BSE-500 companies from Feb 1999 to December 2007 and using monthly stock returns found that the return behavior of the six size-value based portfolios could be more significantly explained by adding size and value factors to the market factor. They found this combination of factors could explain the portfolio returns better and in conformity with the Fama and French model. Manjunatha (2016) shows that portfolio returns are not explained by earnings and earnings growth of portfolios or factors portfolios with the exception of big stocks portfolios. Further, the results show that portfolio returns of small stocks are not explained by earnings and earnings growth of portfolios or factor portfolios. Upadhyay (2017) test the validity of three factors CAPM model proposed by Fama and French (1993) in changed Indian context. Results show that in Indian market, no size effect and a weak value effect exists but size or value of stocks cannot discriminate stocks robustly. Beta is significant and none of the three factors individually can explain the variations in the expected return but two or three factors together can explain to some degree. The ability of three factors CAPM in explaining the expected return increases during low GDP growth period and falls during high GDP growth period.

The literature review shows that the Fama and French three factors model offers better explanation of portfolio returns when portfolios are formed by intersection of size and value of stocks. Hence, there is a need to test if the portfolios formed on different criteria could be explained in a similar manner. Bahl (2007) has suggested this approach, and hence an attempt is made in this study to test the model for 
portfolios formed on the basis of BE/ME ranking. The literature also shows that robust evidence on size and value premiums are required for the emerging Indian market.

\subsection{Objective}

\section{Objectives, Hypothesis, Data and Methodology}

The objective of this paper is to test the relationship between returns of portfolios formed based on book-to-market ratio and the three factors-- market, size and value.

\subsection{Hypothesis}

Based on the available evidence on Fama and French $(1992 ; 1993 ; 1995 ; 1996)$ model and Bahl (2007) the following null hypothesis is formulated.

$\mathbf{H}_{\mathbf{0}}$ : The three factors -- market, size and value -- do not explain the returns of portfolios formed based on book-to-market ratios.

$\mathbf{H}_{1}$ : The three factor model explains the returns of portfolios formed based on bookto-market ratios.

\subsection{Data and Sample}

The study is based on stocks listed and traded on NSE from July 1996 to June 2010. The number of stocks was 387 for the year 1996-97 and this number increased to 1108 for the year 2009-10 (Box 1). Brown \& Warner (1985) suggest that the daily prices are better which provide a very meaningful relationship between risk and return and hence daily prices of stocks and indices are used in this study and it is felt that quarterly, monthly, weekly data do not provide a very meaningful relationship between risk and return. The daily adjusted share prices and Nifty index data collected from the Capital Line are used for calculating daily stock and index returns. The data pertaining to T-91 bills collected from the Reserve Bank of India website was used for calculating daily risk-free returns.

Box 1 Year-Wise Number of NSE Traded Stocks Studied for the Period 1996-2010

\begin{tabular}{|l|c|c|c|c|c|c|c|}
\hline \multicolumn{1}{|c|}{ Year } & $\mathbf{1 9 9 6 - 9 7}$ & $\mathbf{1 9 9 7 - 9 8}$ & $\mathbf{1 9 9 8 - 9 9}$ & $\mathbf{1 9 9 9 - 0 0}$ & $\mathbf{2 0 0 0 - 0 1}$ & $\mathbf{2 0 0 1 - 0 2}$ & $\mathbf{2 0 0 2 - 0 3}$ \\
\hline No. of stocks & 387 & 405 & 411 & 469 & 441 & 449 & 499 \\
\hline Year & $2003-04$ & $2004-05$ & $2005-06$ & $2006-07$ & $2007-08$ & $2008-09$ & $2009-10$ \\
\hline No. of stocks & 537 & 608 & 662 & 787 & 961 & 1035 & 1108 \\
\hline
\end{tabular}

Daily returns for all the stocks, market and T-91 bills are calculated from July of year $\mathrm{t}$ to June of year $\mathrm{t}+1$ for the study period. For each year, average daily returns of the stocks, market (Nifty index) and risk-free returns are calculated from these daily values. Nifty returns are used as market proxy. The portfolios are formed each year at the end of June. These portfolios are constructed on equal weight basis as suggested by Lakonishok, Shliefer and Vishny (1994) and the portfolio returns are found as an average of the returns of stocks in the portfolio. 
Box 2 Definition of Different Variables used in the Study

\begin{tabular}{|l|l|}
\hline \multicolumn{1}{|c|}{ Variables } & \multicolumn{1}{c|}{ Definition } \\
\hline $\begin{array}{l}\mathrm{S} / \mathrm{H}, \mathrm{S} / \mathrm{M}, \mathrm{S} / \mathrm{L}, \mathrm{B} / \mathrm{H}, \\
\mathrm{B} / \mathrm{M}, \text { and } \mathrm{B} / \mathrm{L}\end{array}$ & $\begin{array}{l}\text { Returns of portfolios formed from the intersection of the two sizes } \\
\text { (small and big) and three BE/ME groups (high, medium and low) }\end{array}$ \\
\hline $\mathrm{S} / \mathrm{H}$ & Returns of portfolio of small cap stocks with high BE/ME ratio \\
\hline $\mathrm{S} / \mathrm{M}$ & Returns of portfolio of small cap stocks with medium BE/ME ratio \\
\hline $\mathrm{S} / \mathrm{L}$ & Returns of portfolio of small cap stocks with low BE/ME ratio \\
\hline $\mathrm{B} / \mathrm{H}$ & $\begin{array}{l}\text { Returns of portfolio of big cap stocks with high BE/ME ratio, also } \\
\text { called "value stocks" }\end{array}$ \\
\hline $\mathrm{B} / \mathrm{M}$ & Returns of portfolio of big cap stocks with medium BE/ME ratio \\
\hline $\mathrm{B} / \mathrm{L}$ & $\begin{array}{l}\text { Returns of portfolio of big cap stocks with low BE/ME ratio, also called } \\
\text { "growth stocks" }\end{array}$ \\
\hline $\mathrm{SMB}$ & $\begin{array}{l}\text { Referred to as size factor portfolio return found as } \\
\text { SMB }=(\mathrm{S} / \mathrm{H}+\mathrm{S} / \mathrm{M}+\mathrm{S} / \mathrm{L}) / 3-(\mathrm{B} / \mathrm{H}+\mathrm{B} / \mathrm{M}+\mathrm{B} / \mathrm{L}) / 3\end{array}$ \\
\hline $\mathrm{HML}$ & $\begin{array}{l}\text { Referred to as value factor portfolio return found as } \\
\text { HML=(S/H+B/H)/2-(S/L+B/L)/2 }\end{array}$ \\
\hline $\mathrm{R}_{\mathrm{m}}-\mathrm{R}_{\mathrm{f}}$ & Market factor: Market returns minus risk-free-return \\
\hline $\mathrm{R}_{\mathrm{p}}-\mathrm{R}_{\mathrm{f}}$ & Portfolio -excess-return: Portfolio return minus risk-free-return \\
\hline $\mathrm{a}, \mathrm{b}, \mathrm{s}, \mathrm{h}$ and $\varepsilon$ & $\begin{array}{l}\text { Intercept (a), slope coefficients of independent variables (b, } \mathrm{s}, \mathrm{h} \text { ) used in } \\
\text { a regression and the error term ( }(\varepsilon) .\end{array}$ \\
\hline
\end{tabular}

Note: Each year the stocks are split into two size groups- small (S) and big (B) based on market capitalization at the end of June. Each group is then split into - low (L) consisting of the bottom $30 \%$, medium $(\mathrm{M})$ with middle $40 \%$ and high $(\mathrm{H})$ with top $30 \%$ of the $\mathrm{BE} / \mathrm{ME}$ sorted stocks. These return values are used for deriving factor portfolio returns. Also, each year the stocks are ranked based on BE/ME ratio and ten stocks portfolios are formed as explained in the box. The returns of these are regressed over the returns of factor portfolios.

\subsection{Methodology \\ 2.4.1 Constructing the Size and Value Sorted Portfolios}

In each year of the sample period, the stocks are split into two groups- big (B) and small (S) - based on whether their market capitalization at the end of June of every year in the sample period is above or below the median for the stocks of the companies included. The financial year end for Indian companies being March, the book equity to market equity ratio (BE/ME) is calculated in this month for all the companies. The stocks are now split into three BE/ME groups- low (L) consisting of the bottom $30 \%$, medium $(\mathrm{M})$ with middle $40 \%$ and high $(\mathrm{H})$ with top $30 \%$ of the value of $\mathrm{BE} / \mathrm{ME}$ for the stocks in the sample. The next step is to construct six portfolios $-\mathrm{S} / \mathrm{L}, \mathrm{S} / \mathrm{M}, \mathrm{S} / \mathrm{H}, \mathrm{B} / \mathrm{L}, \mathrm{B} / \mathrm{M}$, and $\mathrm{B} / \mathrm{H}$ - which are formed from the intersection of the two sizes and three $\mathrm{BE} / \mathrm{ME}$ groups. The explanation for these portfolio formation is given in Box 2.

Daily returns series for all the portfolios are calculated from July of year $t$ to June of year $\mathrm{t}+1$. The process of dividing stocks into portfolios is carried out every year in June. By this time of the year, the accounting information to calculate BE/ME for the previous year is publicly available through the annual reports published at the end of the financial year. Fama and French $(1992 ; 1993 ; 1995 ; 1996)$ documented that the three-factor model does a better job in terms of both the magnitudes of the intercepts 
and the Gibbon, Ross and Shanken test when equal weighted portfolios are constructed like the ones by Lakonishok, Shleifer and Vishny (1994). The annual average daily return of each portfolio is obtained as an average of returns of securities in that portfolio.

\subsubsection{Constructing the Factor Portfolios}

The Fama and French model uses three explanatory variables for explaining the cross section of stock returns. The first is the market-excess-return factor, which is the market index return minus the risk-free return. This is calculated from the Nifty index which is a weighted average of popular securities reflecting market movements at the national level and Treasury bill yields $\left(\mathrm{R}_{\mathrm{m}}-\mathrm{R}_{\mathrm{f}}\right)$.

The second is the size factor--a risk factor in returns relating to size - small minus big $(\mathrm{SMB})$. The simple average of the three big size portfolios $(\mathrm{B} / \mathrm{L}, \mathrm{B} / \mathrm{M}, \mathrm{B} / \mathrm{H})$ is subtracted from the simple average of the three small size portfolios $(\mathrm{S} / \mathrm{L}, \mathrm{S} / \mathrm{M}, \mathrm{S} / \mathrm{H})$ to get the return for the SMB factor. This factor is free from BE/ME effects as it has about the same weighted-average BE/ME.

$\mathrm{SMB}=(\mathrm{S} / \mathrm{L}+\mathrm{S} / \mathrm{M}+\mathrm{S} / \mathrm{H}) / 3-(\mathrm{B} / \mathrm{L}+\mathrm{B} / \mathrm{M}+\mathrm{B} / \mathrm{H}) / 3$

The third factor is value factor - high minus low (HML). Each year, the difference between the average of the returns on the two high $\mathrm{BE} / \mathrm{ME}$ portfolios $(\mathrm{S} / \mathrm{H}$ and $\mathrm{B} / \mathrm{H})$ and the two low $\mathrm{BE} / \mathrm{ME}$ portfolios $(\mathrm{S} / \mathrm{L}$ and $\mathrm{B} / \mathrm{L})$ is calculated. It is free of size effects.

$\mathrm{HML}=(\mathrm{S} / \mathrm{H}+\mathrm{B} / \mathrm{H}) / 2-(\mathrm{S} / \mathrm{L}+\mathrm{B} / \mathrm{L}) / 2$

Since market factor $\mathrm{R}_{\mathrm{m}}-\mathrm{R}_{\mathrm{f}}$, size factor $\mathrm{SMB}$ and value factor $\mathrm{HML}$ are hypothesised to influence the portfolio excess returns as predicted by the Fama and French (1995) model, multiple regressions of portfolio excess returns over the three factors are carried out for testing the same. All these variables and their definitions are provided in Box 2.

\subsubsection{Constructing Ten Stocks Portfolios based on BE/ME Ratio}

The stocks are sorted each year for the study period of fourteen years on the basis of $\mathrm{BE} / \mathrm{ME}$ ratio and form first portfolio consisting of first ten stocks (stock 1, 2...10), second portfolio consisting of next ten stocks $(11,12 \ldots .20)$, similarly we form totally thirty eight portfolios. This method of ranking will help us to know the high $\mathrm{BE} / \mathrm{ME}$, medium $\mathrm{BE} / \mathrm{ME}$ and low $\mathrm{BE} / \mathrm{ME}$ and test whether three factors explain the returns of portfolio. The daily returns for the portfolios are found for all the years of the study and their portfolio excess returns of these are regressed over the daily returns of market factor $\left(\mathrm{R}_{\mathrm{m}}-\mathrm{R}_{\mathrm{f}}\right)$, size factor $(\mathrm{SMB})$ and value factor $(\mathrm{HML})$. This is done to see if the Fama and French multi factor model holds well when the portfolios are formed on $\mathrm{BE} / \mathrm{ME}$ ratios.

\subsubsection{Multiple Regression Over Market Factor $\left(R_{m}-R_{f}\right)$, Size Factor SMB and Value Factor HML for Excess Returns of Portfolios Consisting of First Top Ten, Second Top Ten...etc based on BE/ME Ratio}

$$
\mathrm{R}_{\mathrm{p}}-\mathrm{R}_{\mathrm{f}}=\mathrm{a}+\mathrm{b}\left(\mathrm{R}_{\mathrm{m}}-\mathrm{R}_{\mathrm{f}}\right)+\mathrm{s}(\mathrm{SMB})+\mathrm{h}(\mathrm{HML})+\varepsilon
$$


The values of $a, b$, s and $h$; their $t$ values; the adjusted $R^{2}$ value; $F$ value and $p$ values are studied to see if the factors together capture the cross-sectional variation in portfolio-excess-returns. The purpose is to see if the returns of portfolios formed on $\mathrm{BE} / \mathrm{ME}$ ratio criteria alone are explained by the three factors of Fama and French.

\section{Results and Analysis}

The present study has been conducted by using a combination of market, size and value factors as done in Fama and French (1995) to find out the extent to which these variables explain portfolio returns. The intercept and slope co-efficient values are tested using the t-test and the overall fit of the regression is tested using the F-test at 5 per cent level of significance. Intercepts and coefficient estimates of market, size and value factors are significant if their corresponding $p$ values are less than the level of significance. The detailed results of the portfolios and the explanatory power of each of the three factors are given in Table 1.

Table 1 shows that in 92.11 per cent of the cases the p-values corresponding to the F-values of the three-factor regression are significant. Therefore we conclude that all the three factors -market, size and value--together explain the portfolio returns. Further we test whether the p-values of the corresponding F-values for overall regression are less than 0.05 for three $\mathrm{BE} / \mathrm{ME}$ portfolios. The result show that all three factors explain the returns of portfolios formed based on high BE/ME ratio in 100 percent of the cases. Similarly for the medium and low BE/ME portfolios, all three factors explain portfolio returns to the extent of 94 percent and 91 percent, respectively. Therefore, we accept the alternate hypothesis that the three factor model explain the returns of portfolios formed based on BE/ME ratios.

We also found that 97 percent of market factor, 71 percent of the size factor and 53 percent of value factor independently explain the returns of portfolios formed based on BE/ME ratio. Therefore, we accept the alternate hypothesis that market, size and value factors explain the returns of portfolios formed based on BE/ME ratios.

When the market, size and value factors are considered individually for the high $\mathrm{BE} / \mathrm{ME}$ portfolios the $\mathrm{p}$ values corresponding the slope co-efficient of these factors show that these are significant in 100 percent, 100 percent and 81.82 percent, respectively. Therefore, we conclude that market, size and value factors individually explain portfolio returns. Similarly for the medium BE/ME portfolios the $p$ values are significant in 93.75 percent, 68.75 percent and 68.75 percent for market, size and value factors, respectively. Therefore, for medium BE/ME portfolios also the market, size and value factors explain portfolio returns but the explanatory power of these is not as strong as in case of high BE/ME portfolios. For low BE/ME portfolios, the $\mathrm{p}$ values are significant in 90.91, 36.36 and 0 percentage cases for market, size and value, respectively. This shows that in case of low BE/ME portfolios only market factor explains the portfolio returns but size has low explanatory power and value has no explanatory power. Further, the explanatory of power of these factors decrease as we move from high to medium and medium to low BE/ME portfolios. The overall results indicate that market has a high explanatory power in all three portfolios, followed by size and value. The results of this indicate that three factors individually explain portfolio returns in high and medium BE/ME portfolios. When all the BE/ME portfolios are considered together; market, size and value factors explain portfolio returns in $97.37,71.05$ and 52.63 percentages, respectively. Therefore, we conclude that market has the highest explanatory power followed by 
size and value in BE/ME portfolios. These results are comparable to those of Fama and French (1995), however, our results do not tally with those of Fama and French (1995) for the low BE/ME portfolios. The results of the three factors model conform to Indian studies undertaken by Bahl (2007).

\section{Summary and Conclusions}

The security/portfolio returns are dependent on many factors. This paper attempts to test the validity of the three factor model to explain the portfolio returns as envisaged in Fama and French (1995). The overall conclusions of this study based on 38 different portfolios size are summarized below

\begin{tabular}{|l|l|}
\hline Portfolio Descriptions & \multicolumn{1}{c|}{ What Factors Explain the Returns of the Portfolios? } \\
\hline $\begin{array}{l}\text { All Portfolios formed on } \\
\text { the basis of BE/ME }\end{array}$ & $\begin{array}{l}\text { All three factors explain the returns in 92.11 percent of the thirty eight } \\
\text { portfolios. }\end{array}$ \\
\hline High BE/ME portfolios & $\begin{array}{l}\text { All three factors explain the returns in 100 percent of the eleven portfolios. } \\
\text { Portfolio returns are explained by Market, size and value factors explain in 100, } \\
100 \text { and 81.82 percentages, respectively. }\end{array}$ \\
\hline $\begin{array}{l}\text { Medium BE/ME } \\
\text { portfolios }\end{array}$ & $\begin{array}{l}\text { All three factors explain the returns in 94 percent of the sixteen portfolios. } \\
\text { Portfolio returns are explained by Market, size and value factors in 93.75, 68.75 } \\
\text { and 68.75 percentages, respectively. }\end{array}$ \\
\hline Low BE/ME portfolios & $\begin{array}{l}\text { All three factors explain the returns in 91 percent of the eleven portfolios. } \\
\text { Portfolio returns are explained by Market, size and value factors in 90.91, 36.36 } \\
\text { and 0 percentages, respectively. }\end{array}$ \\
\hline
\end{tabular}

The results show that the three factor model explains the returns of portfolios formed based on BE/ME ratios. We found that market, size and value factors have better explanatory power for explaining the returns of the portfolio formed on high $\mathrm{BE} / \mathrm{ME}$ ratio. Further, analysis shows that in medium BE/ME portfolios also, three factors explain portfolio returns but the explanatory power of these is not as strong as in case of high $\mathrm{BE} / \mathrm{ME}$ portfolios. In case of low BE/ME portfolios only market factor explains the portfolio returns and size has low explanatory power and value has no explanatory power. Further, the explanatory of power of these factors decrease as we move from high to medium and medium to low BE/ME portfolios. The overall results indicate that market has a high explanatory power in all three portfolios, followed by size and value. The results indicate that three factors individually explain portfolio returns in high and medium BE/ME portfolios. When all the BE/ME portfolios are considered together market has the highest explanatory power, followed by size and value. The results of this paper may help the fund managers to advise the investors and they may help in cost of capital calculations required for capital investment decisions. Further research on the combination of market, firm specific factors and additional factors such as momentum is needed to enlarge the understanding of factors model. There is also a need to test, in Indian context, whether the five-factor model performs better than the three-factor model as found by Fama \& French (2015).

\section{References}

1. Ajili, Souad, The Capital Asset Pricing Model and the Three Factor Model of Fama and French Revisited in the Case of France, Working Paper, 2005. 
2. Bahl, Bhavna, Testing the Fama and French Three Factor Model and its Variants for the Indian Stock Returns, Availed at www.ssrn.com, dated October 20, 2007.

3. Barber, Board, John, M and Lyon D., Firm Size, Book-to-Market Ratio, and Security Returns: A Hold out Sample of Financial Firms, Journal of Finance 52(2), 1997, 875-883.

4. Beltratti, A. and Trio, M., The Cross-Section of Risk Premium in the Italian Stock Market, Economic Notes 31(3), 2002, 389-416.

5. Black F., Jensen, M.C. and Scholes, M., The Capital Asset Pricing Model: Some Empirical Tests, in Jenson (ed.), Studies in Theory of Capital markets, (New York: Praeger), 1972.

6. Brown, Stephen J. and Warner, Using Daily Stock Returns, The Case of Event Studies, Journal of Financial Economics 14(2), 1985, 3-31

7. Bun doo, Sunil, K, An Augmented Fama and French Three Factor Model: New Evidence from an Emerging Stock Market at http://www.melbournecentre.com.au/Finsia_MCFS. Accessed on Dec 10, 2007, $1-25$.

8. Cakici Nusret, Frank J. Fabozzi, Sinan Tan, Size, Value and Momentum in Emerging Market Stock Returns, Emerging Market Review, 16(1), 2013, 46-65

9. Connor Gregory and Sehgal Sanjay, Tests of the Fama and French Model in India, Decision 30 (2), 2003, 1-20.

10. Davis James L, Eugene, Fama F. and Kenneth French R., Characteristics, Covariance and Average Returns: 1929 to1997, Journal of Finance 55(1), 2000, 389-406.

11. Faff, Robert, A simple test of the Fama and French model using daily data: Australian evidence, Applied Financial Economics, 14, 2004, 83-92

12. Fama, Eugene F. and Kenneth French R., the Cross-Section of Expected Stock Returns, Journal of Finance 47(2), 1992, 427-465.

13. Fama, Eugene F. and Kenneth French R., Common Risk Factors in the Returns on the Stocks and Bonds, Journal of Financial Economics 33(3), 1993, 3-56.

14. Fama, Eugene F. and Kenneth French R., Size And Book-to-Market Factors In Earnings and Returns, Journal of Finance 50(1), 1995, 131-155.

15. Fama, Eugene F. and Kenneth French R., The CAPM is Wanted, Dead or Alive, Journal of Finance 51(5), 1996a, 1947-1958.

16. Fama, Eugene F. and Kenneth French R., Multifactor explanations of asset pricing anomalies, Journal of finance, 51(1), 1996b, 55-87.

17. Fama, Eugene F. and Kenneth French R., Value Verses Growth: The International Evidence, Journal of Finance 53(6), 1998, 1975-1999.

18. Fama, Eugene F. and Kenneth French R., Forecasting Profitability and Earnings, Journal of Business 73(2), 2000, 161-75.

19. Fama, Eugene F. and Kenneth French R, Size, value, and momentum in international stock returns, Journal of financial economics, 105(3), 2012, 457472.

20. Fama, Eugene F. and Kenneth French R, A Five-Factor Asset Pricing Model, Journal of Financial Economics, 116(2), 2015, 1-22

21. Gaunt, Clive (2004), "Size and Book to Market Effects and the Fama French Three Factor Asset Pricing Model: Evidence from the Australian Stock market", Accounting and Finance, 44(1), 2004, 27-44. 
22. Homsud, Nopbhanon, Jatuphon Wasunsakul., Sirina Phuangnark., JitwatthanaJoongpong, A Study of Fama and French Three Factors Model and Capital Asset Pricing Model in the Stock Exchange of Thailand, International Research Journal of Finance and Economics, 4(25), 2009, 35-47

23. Hou, K., Karolyi, G.A., Kho, B.C., What factors drive global stock returns? Review of Financial Studies 4(24), 2011, 2527-2574.

24. Kapur, Varun, Is the Fama and French model a good indicator of market sectoral performance? Study of the relationship between excess industry returns and the Fama and French three factor model, Honors Thesis. New York University May 2007.

25. Kothari, S.P., and Shanken Jay, In Defense of Beta, Journal of Applied Corporate Finance 8(4), 1995, 53-58.

26. Kothari, S.P., Shanken, Jay, and Sloan, Richard G., Another Look at the CrossSection of Expected Stock Returns, Journal of Finance 50(1), 1995, 185-224.

27. Lakonishok, Josef, Andrei Shleifer, and Robert, Vishny W., Contrarian Investment, Extrapolation and Risk, Journal of Finance 49(5), 1994, 1541-1578

28. Loughran, Tim, Book-to-Market across Firm Size, Exchange, and Seasonality, Journal of Financial and Quantitative Analysis 32, 1997, 249-268.

29. Manjunatha T. An Empirical Testing of Relationship between Earnings and Portfolio Returns in Indian Capital Market, Finance India, 5(3), 2016, 1185 1201.

30. Nartea, G.V. and Djajadikerta, H., Size and Book to Market Effects and the Fama-French Three-Factor Model: Evidence from New Zealand, Proceedings of the UM-FBA Asian Business Conference, Kuala Lumpur, Malaysia, 2005, 510521.

31. Taneja, Yash Pal., Revisiting Fama French Three-Factor Model in Indian Stock Market,Vision-The Journal of Business Perspective · 14(4), 2010, 1-8.

32. Upadhyay Rajeev Kumar, Modelling Stock Returns in India: Fama and French Revisited, Pacific Business Review International, 9(7), 2017, 38-45.

\section{Websites}

1. www.bseindia.com. Accessed on 14-02-2016

2. Www.investmentmap.com/Indianstockexchanges.htm Accessed on 12-4-2016

3. www.nseindia.com Accessed on 14-02-2016

4. www.nseindia.com/research/nse fact book. Accessed on 14-04-2016

5. www.nseindia.com/ Indices. Indian Securities Market: A Review, Volume XIV 2015

6. www.rbi.org.in/statistics/Auctions of 91-day Government of India treasury bills. Accessed on 14-04-2016.

7. www.nseindia.com/research/nse fact book as on 14-02-2016. 
7. Table

\begin{tabular}{|c|c|c|c|c|c|c|c|}
\hline \multirow{2}{*}{$\begin{array}{c}\text { BE/ME } \\
\text { Rank } \\
\text { Portfolio }\end{array}$} & \multirow{2}{*}{$\begin{array}{l}\text { Regrn. } \\
\text { Output }\end{array}$} & $\begin{array}{c}\text { Interce } \\
\text { pt }\end{array}$ & Mkt. & SMB & HML & \multirow{2}{*}{\multicolumn{2}{|c|}{$\operatorname{Adj} R^{2}$}} \\
\hline & & $\mathbf{a}$ & B & $\mathbf{S}$ & H & & \\
\hline \multirow{2}{*}{$\begin{array}{l}\text { High } \\
\text { BE/ME } \\
\text { Portfolio 1 } \\
\end{array}$} & Coeffts. & 0.0002 & 1.3823 & 1.6007 & 1.6724 & \multirow{2}{*}{\multicolumn{2}{|c|}{0.6867}} \\
\hline & $p$ values & 0.9965 & 0.0145 & 0.0086 & 0.0010 & & \\
\hline \multirow{2}{*}{ Portfolio 2} & Coeffts. & -0.0055 & 1.3306 & 2.0160 & 1.1365 & \multirow{2}{*}{\multicolumn{2}{|c|}{0.6935}} \\
\hline & $\mathrm{p}$ values & 0.9098 & 0.0129 & 0.0014 & 0.0075 & & \\
\hline \multirow{2}{*}{ Portfolio 3} & Coeffts. & -0.0477 & 1.2723 & 1.6060 & 1.0520 & \multirow{2}{*}{\multicolumn{2}{|c|}{0.7013}} \\
\hline & $p$ values & 0.2577 & 0.0066 & 0.0021 & 0.0045 & & \\
\hline \multirow{2}{*}{ Portfolio 4} & Coeffts. & -0.0143 & 1.2883 & 1.3137 & 0.9274 & \multirow{2}{*}{\multicolumn{2}{|c|}{0.7482}} \\
\hline & $p$ values & 0.6610 & 0.0015 & 0.0018 & 0.0024 & & \\
\hline \multirow{2}{*}{ Portfolio 5} & Coeffts. & -0.0030 & 1.2449 & 1.2715 & 0.5551 & \multirow{2}{*}{\multicolumn{2}{|c|}{0.5325}} \\
\hline & $p$ values & 0.9475 & 0.0141 & 0.0161 & 0.1179 & & \\
\hline \multirow{2}{*}{ Portfolio 6} & Coeffts. & 0.0117 & 1.1530 & 1.2163 & 0.6523 & \multirow{2}{*}{\multicolumn{2}{|c|}{0.5036}} \\
\hline & $p$ values & 0.7981 & 0.0203 & 0.0197 & 0.0716 & & \\
\hline \multirow{2}{*}{ Portfolio 7} & Coeffts. & -0.0253 & 1.1883 & 1.3580 & 1.0383 & \multirow{2}{*}{\multicolumn{2}{|c|}{0.6778}} \\
\hline & $p$ values & 0.5184 & 0.0073 & 0.0044 & 0.0036 & & \\
\hline \multirow{2}{*}{ Portfolio 8} & Coeffts. & -0.0548 & 1.5036 & 1.0627 & 1.0297 & \multirow{2}{*}{\multicolumn{2}{|c|}{0.8220}} \\
\hline & $p$ values & 0.0630 & 0.0001 & 0.0020 & 0.0003 & & \\
\hline \multirow{2}{*}{ Portfolio 9} & Coeffts. & -0.0364 & 1.5334 & 1.0424 & 1.0336 & \multirow{2}{*}{\multicolumn{2}{|c|}{0.6288}} \\
\hline & $p$ values & 0.4050 & 0.0029 & 0.0295 & 0.0067 & & \\
\hline \multirow{2}{*}{ Portfolio 10} & Coeffts. & -0.0346 & 1.2920 & 1.5863 & 0.8286 & \multirow{2}{*}{\multicolumn{2}{|c|}{0.6704}} \\
\hline & $p$ values & 0.4137 & 0.0068 & 0.0026 & 0.0183 & & \\
\hline \multirow{2}{*}{ Portfolio 11} & Coeffts. & -0.0505 & 1.3891 & 1.2857 & 0.8653 & \multirow{2}{*}{\multicolumn{2}{|c|}{0.6741}} \\
\hline & $p$ values & 0.2113 & 0.0028 & 0.0061 & 0.0102 & & \\
\hline \multicolumn{5}{|c|}{$\begin{array}{c}\text { Number of high BE/ME Portfolios with } p \text { values } \\
\qquad \begin{array}{c}<0.05\end{array}\end{array}$} & 11 & 11 & 9 \\
\hline \multicolumn{5}{|c|}{$\begin{array}{c}\text { Percentage of high BE/ME Portfolios with } p \\
\text { values }<0.05\end{array}$} & 100 & 100 & 81.82 \\
\hline
\end{tabular}

\begin{tabular}{|c|c|c|c|c|c|c|c|}
\hline \multirow{2}{*}{$\begin{array}{l}\text { Medium } \\
\text { BE/ME } \\
\text { Portfolio } 12\end{array}$} & Coeffts. & -0.0268 & 1.3517 & 1.1243 & 0.9103 & \multirow{2}{*}{0.5871} & \multirow{2}{*}{$\begin{array}{l}7.1613 \\
0.0075\end{array}$} \\
\hline & $p$ values & 0.5410 & 0.0028 & 0.0020 & 0.0090 & & \\
\hline \multirow{2}{*}{ Portfolio 13} & Coeffts. & -0.0502 & 1.8079 & 1.2780 & 0.9574 & \multirow{2}{*}{0.6359} & \\
\hline & $p$ values & 0.3136 & 0.0022 & 0.0204 & 0.0190 & & 00088 \\
\hline \multirow{2}{*}{ Portfolio 14} & Coeffts. & -0.0504 & 1.2754 & 1.4087 & 0.8130 & \multirow{2}{*}{0.7125} & 11.7396 \\
\hline & $\mathrm{p}$ values & 0.1770 & 0.0028 & 0.0020 & 0.0090 & & 0.0013 \\
\hline \multirow{2}{*}{ Portfolio 15} & Coeffts. & -0.0689 & 1.3432 & 1.1922 & 0.8491 & \multirow{2}{*}{0.5728} & 6.8098 \\
\hline & $p$ values & 0.1450 & 0.0081 & 0.0192 & 0.0228 & & 0.0088 \\
\hline \multirow{2}{*}{ Portfolio 16} & Coeffts. & -0.0490 & 1.5934 & 1.2687 & 0.7055 & \multirow{2}{*}{0.6902} & 10.6554 \\
\hline & $p$ values & 0.2314 & 0.0013 & 0.0073 & 0.0299 & & 0.0019 \\
\hline \multirow{2}{*}{ Portfolio 17} & Coeffts. & 0.0044 & 0.6737 & 1.3187 & 0.6997 & \multirow{2}{*}{0.6323} & 8.4528 \\
\hline & $p$ values & 0.8964 & 0.0536 & 0.0022 & 0.0149 & & 043 \\
\hline \multirow{2}{*}{ Portfolio 18} & Coeffts. & 0.0044 & 0.8795 & 0.7367 & 0.5184 & \multirow{2}{*}{0.2358} & 2.3369 \\
\hline & $p$ values & 0.9280 & 0.0746 & 0.1429 & 0.1604 & & 0.1353 \\
\hline
\end{tabular}




\begin{tabular}{|l|l|c|c|c|c|c|c|}
\hline \multirow{2}{*}{ Portfolio 19} & Coeffts. & -0.0448 & 1.7523 & 1.2374 & 0.8345 & \multirow{2}{*}{0.5697} & 6.7364 \\
& p values & 0.4028 & $\mathbf{0 . 0 0 4 5}$ & $\mathbf{0 . 0 3 3 7}$ & 0.0484 & & 0.0092 \\
\hline \multirow{2}{*}{ Portfolio 20} & Coeffts. & -0.0337 & 1.2691 & 1.1136 & 0.6193 & \multirow{2}{*}{0.6386} & 8.6564 \\
\cline { 2 - 6 } & p values & 0.3645 & $\mathbf{0 . 0 0 3 3}$ & $\mathbf{0 . 0 0 9 5}$ & $\mathbf{0 . 0 3 6 5}$ & & 0.0039 \\
\hline \multirow{2}{*}{ Portfolio 21} & Coeffts. & -0.0395 & 1.6016 & 0.9426 & 0.5888 & \multirow{2}{*}{0.5701} & 6.7466 \\
\cline { 2 - 6 } & p values & 0.3935 & $\mathbf{0 . 0 0 3 1}$ & $\mathbf{0 . 0 5 5 3}$ & 0.0963 & & 0.0091 \\
\hline
\end{tabular}

\begin{tabular}{|c|c|c|c|c|c|c|c|}
\hline \multirow{2}{*}{ Portfolio 22} & Coeffts. & -0.0624 & 1.4680 & 0.8106 & 0.7962 & \multirow{2}{*}{0.4305} & \multirow{2}{*}{$\begin{array}{l}4.2754 \\
0.0348\end{array}$} \\
\hline & $p$ values & 0.2507 & 0.0120 & 0.1379 & 0.0574 & & \\
\hline \multirow{2}{*}{ Portfolio 23} & Coeffts. & -0.0284 & 1.0670 & 0.5022 & 0.6789 & \multirow{2}{*}{0.2762} & 2.6535 \\
\hline & $\mathrm{p}$ values & 0.5611 & 0.0368 & \begin{tabular}{l|l}
0.3051 & (
\end{tabular} & 0.0759 & & 0.1058 \\
\hline \multirow{2}{*}{ Portfolio 24} & Coeffts. & -0.0638 & 1.6996 & 0.9095 & 0.9168 & \multirow{2}{*}{0.7822} & 16.5637 \\
\hline & $p$ values & 0.0587 & 0.0001 & \begin{tabular}{l|l}
0.0113 & (
\end{tabular} & 0.0017 & & 0.0003 \\
\hline \multirow{2}{*}{ Portfolio 25} & Coeffts. & -0.0360 & 1.3865 & \begin{tabular}{l|l}
0.7801 & (
\end{tabular} & 0.6866 & \multirow{2}{*}{0.4926} & 5.2066 \\
\hline & $p$ values & 0.4277 & 0.0068 & 0.0981 & 0.0547 & & 0.0201 \\
\hline \multirow{2}{*}{ Portfolio 26} & Coeffts. & -0.0622 & 1.5605 & \begin{tabular}{l|l}
0.8461 & (
\end{tabular} & 0.7111 & \multirow{2}{*}{0.6853} & 10.4350 \\
\hline & $\mathrm{p}$ values & 0.0988 & 0.0006 & 0.0302 & 0.0166 & & 0.0020 \\
\hline \multirow{2}{*}{ Portfolio 27} & Coeffts. & -0.0634 & 1.5965 & 1.4831 & 0.4978 & \multirow{2}{*}{0.5277} & 5.8410 \\
\hline & $\mathrm{p}$ values & 0.2810 & 0.0120 & 0.0218 & 0.2453 & & 0.0143 \\
\hline \multicolumn{3}{|c|}{$\begin{array}{l}\text { Number of medium BE/ME Portfolios } \\
\text { with } p \text { values }<0.05\end{array}$} & 15 & 11 & 11 & & \\
\hline \multicolumn{3}{|c|}{$\begin{array}{l}\text { Percentage of medium BE/ME } \\
\text { Portfolios with } p \text { values }<0.05\end{array}$} & 93.75 & 68.75 & 68.75 & & \\
\hline \multirow{2}{*}{$\begin{array}{l}\text { Low BE/ME } \\
\text { Portfolio } 28\end{array}$} & Coeffts. & -0.0296 & 1.1086 & 0.8995 & 0.4830 & \multirow{2}{*}{0.3968} & 3.8512 \\
\hline & $\mathrm{p}$ values & 0.5240 & 0.0247 & \begin{tabular}{l|l}
0.0682 \\
\end{tabular} & 0.1678 & & 0.0455 \\
\hline \multirow{2}{*}{ Portfolio 29} & Coeffts. & -0.0456 & 1.2058 & \begin{tabular}{l|l}
1.4801 & ( \\
\end{tabular} & 0.7073 & \multirow{2}{*}{0.5560} & 6.4275 \\
\hline & $\mathrm{p}$ values & 0.3491 & 0.0197 & 0.0088 & 0.0619 & & 0.0106 \\
\hline \multirow{2}{*}{ Portfolio 30} & Coeffts. & -0.0673 & 1.5823 & 1.0310 & 0.6126 & \multirow{2}{*}{0.6384} & 8.6517 \\
\hline & $\mathrm{p}$ values & 0.1206 & 0.0017 & \begin{tabular}{l|l}
0.0244 & ( \\
\end{tabular} & 0.0589 & & 0.0039 \\
\hline \multirow{2}{*}{ Portfolio 31} & Coeffts. & -0.0439 & 1.1018 & 1.3008 & 0.5006 & \multirow{2}{*}{0.6201} & 8.0717 \\
\hline & $\mathrm{p}$ values & 0.2589 & 0.0093 & \begin{tabular}{l|l}
0.0047 \\
\end{tabular} & 0.0888 & & 0.0050 \\
\hline \multirow{2}{*}{ Portfolio 32} & Coeffts. & -0.0422 & 1.4383 & \begin{tabular}{l|l}
0.7781 & \\
\end{tabular} & 0.3841 & \multirow{2}{*}{0.5402} & 6.0918 \\
\hline & $p$ values & 0.3331 & 0.0041 & \begin{tabular}{l|l}
0.0851 \\
\end{tabular} & 0.2301 & & 0.0126 \\
\hline \multirow{2}{*}{ Portfolio 33} & Coeffts. & -0.0276 & 1.4089 & \begin{tabular}{l|l}
0.8412 \\
\end{tabular} & 0.2271 & \multirow{2}{*}{0.6874} & 10.5292 \\
\hline & $\mathrm{p}$ values & 0.4158 & 0.0009 & \begin{tabular}{l|l}
0.0249 & ( \\
\end{tabular} & 0.3576 & & 0.0019 \\
\hline \multirow{2}{*}{ Portfolio 34} & Coeffts. & 0.0098 & 1.6006 & \begin{tabular}{l|l}
0.4165 & ( \\
\end{tabular} & 0.0831 & \multirow{2}{*}{0.1975} & 2.0665 \\
\hline & $\mathrm{p}$ values & 0.9030 & 0.0532 & 0.5983 & 0.8860 & & 0.1685 \\
\hline Portfolio 35 & Coeffts. & -0.0359 & 1.3263 & \begin{tabular}{l|l}
0.6628 \\
\end{tabular} & 0.3466 & & 5.7733 \\
\hline Portfolio 35 & $\mathrm{p}$ values & 0.3758 & 0.0044 & \begin{tabular}{|l|l}
0.1116 & ( \\
\end{tabular} & 0.2445 & 0 & 0.0148 \\
\hline & Coeffts. & -0.0024 & 1.0956 & 0.4180 & \begin{tabular}{|l|}
-0.1123 \\
\end{tabular} & 0.4350 & 4.3366 \\
\hline & $\mathrm{p}$ & 0.9553 & 0.0183 & 0.3296 & \begin{tabular}{|l|l|}
5 & 0.7170 \\
\end{tabular} & & 0.0335 \\
\hline
\end{tabular}




\begin{tabular}{|c|c|c|c|c|c|c|c|}
\hline & values & & & & & & \\
\hline \multirow{2}{*}{ Portfolio 37} & Coeffts. & -0.0051 & 1.2658 & 0.6644 & 0.0477 & \multirow{2}{*}{0.4266} & \multirow{2}{*}{$\begin{array}{l}4.2236 \\
0.0359\end{array}$} \\
\hline & $\begin{array}{l}\mathrm{p} \\
\text { values }\end{array}$ & 0.9162 & 0.0167 & 0.1814 & 0.8917 & & \\
\hline \multirow[b]{2}{*}{ Portfolio 38} & Coeffts. & -0.0115 & 1.2273 & 0.8513 & -0.0792 & \multirow{2}{*}{0.5191} & \multirow{2}{*}{$\begin{array}{l}5.6775 \\
0.0156\end{array}$} \\
\hline & $\begin{array}{l}\mathrm{p} \\
\text { values }\end{array}$ & 0.7988 & 0.0140 & 0.0777 & 0.8094 & & \\
\hline \multicolumn{3}{|c|}{$\begin{array}{l}\text { Number of low BE/ME Portfolios with } \\
\text { p values }<0.05\end{array}$} & 10 & 04 & 00 & & \\
\hline \multicolumn{3}{|c|}{$\begin{array}{l}\text { Percentage of low BE/ME Portfolios } \\
\text { with } p \text { values }<0.05\end{array}$} & 90.91 & 36.36 & 00 & & \\
\hline \multicolumn{3}{|c|}{$\begin{array}{l}\text { All three category Portfolios with } p \\
\text { values }<0.05\end{array}$} & 37 & 27 & 20 & & $\begin{array}{c}35 \\
\text { F sig }\end{array}$ \\
\hline \multicolumn{3}{|c|}{ Percentage of Significant values } & 97.37 & 71.05 & 52.63 & & 92.11 \\
\hline
\end{tabular}

\section{About Our Authors}

T. Manjunatha is Professor, Department of M.B.A, Visvesvaraya Technological University BDT College of Engineering, Davangere, Karnataka. He earned his $\mathrm{Ph}$. D, M.B.A and B.B.M from Mangalore University. He has published his research papers in leading national and International journals namely Finance India, Vikalpa, Decision, AIMS International Journal of Management, Journal of Management \& Public Policy etc.(Visit http://scholar.google.com/citations? User = 9wuCgJoAAAAJ for his research journal publications and impact factor of the citations). He has published two books in the area of his research. His area of interest is Security Analysis, Capital Asset Pricing Model, Mutual Funds, single index model Arbitrage Pricing Model, Optimum portfolio, infrastructure financing private equity. $\mathrm{He}$ is registered $\mathrm{Ph}$. D guide for Visvesvaraya Technological University. He can be reached at tmmanju87@gmail.com

T. Mallikarjunappa is Professor, Department of Business Administration, Mangalore University, Karnataka. He earned his Ph. D, M.B.A and B.B.M from University of Mysore. He is an Associate Member of the Institute of Cost Accountants of India, Kolkata. He has published his research papers in leading national and International journals. He has won many Awards and prizes in paper presentations in national and international conferences. His area of interest is Efficient Market Hypotheses, Event Studies, Random Walk Hypothesis, Capital Structure Decisions, Security Analysis, Capital Asset Pricing Model, Mutual Funds, Derivatives, Single Index Model, Arbitrage Pricing Model, Portfolio Performance, Optimum portfolio, Supply Chain Management, Derivatives - Options and Futures, Mergers and Acquisitions, market micro structure, financing manufacturing companies, infrastructure financing, private equity, commodities market etc. He is registered $\mathrm{Ph}$. D guide for Mangalore University. He can be reached at tmmallik@yahoo.com 